\title{
Soft Skills in an Online Class
}

\author{
Kimberly A. Moore ${ }^{1,3,5}$ and Brian J. Pearson ${ }^{2,4}$
}

ADDITIONAL INDEX WORDs. professional skills, teaching, asynchronous, distance education

Summary. The development of course content and assignments focused on basic horticultural knowledge and theory (hard skills) in an online setting is relatively straightforward and uncomplicated. However, it is slightly more challenging to improve a student's soft skills like communication, problem solving, critical observation, and professionalism in an asynchronous online classroom environment. To address this challenge, we developed assignments, such as the challenge question, that focused on having students solve situational horticulture problems. In another assignment, we gave students data from an experiment and asked them to summarize and interpret the data. The recent addition of an online scholars ignite assignment (3-minute thesis competition) has turned each student into the teacher for a brief moment and makes the student an active learner and active listener. The addition of etiquette rules to the syllabus, weekly online tasks, and reminders help to develop professionalism and time management skills in addition to organization skills. It is impossible to cover all soft skills in any class but by offering various assignments and assessments, many soft skills are potentially improved.

A ccording to recent studies, all higher education will have an online educational experience in some form during their academic career (Sener, 2012). An online course is defined as one in which $80 \%$ of the course content is delivered online while a blended course blends online (30\% to $79 \%$ ) with face-to-face delivery (Allen et al., 2016). In Fall 2014, of the 5.8 million distance education students, 2.58 million were taking all of their courses at distance, while 2.97 million were taking some, but not all courses at a distance (Allen et al., 2016). Most students will take at least one online course per year with online courses comprising $20 \%$ of a student's total credit hours (Sener, 2012). A survey among 2800 college and university administrators reported that online course offerings are critical to a majority (63\%) of institutions' long-term strategies (Allen et al., 2016). In this same survey, $71 \%$ of

This article was part of the workshop "Developing Soft Skills in Tomorrow's Leaders" held 10 Aug. 2016, during the ASHS Annual Conference, Atlanta, GA, and sponsored by the ASHS Teaching Methods Working Group.

${ }^{1}$ Department of Environmental Horticulture, University of Florida, Fort Lauderdale Research and Education Center, 3205 College Avenue, Davie, FL 33314 ${ }^{2}$ Department of Environmental Horticulture, University of Florida, Mid-Florida Research and Education Center, 2725 S. Binion Road, Apopka, FL 32703

${ }^{3}$ Professor

${ }^{4}$ Assistant Professor

${ }^{5}$ Corresponding author. E-mail: klock@ufl.edu.

doi: 10.21273/HORTTECH03672-17 academic leaders felt online education was similar or superior to traditional face-to-face instruction. Continuing to develop successful online courses for this growing market is a challenge.

Higher education has focused on student memorization of core content and the recall of facts, but the value of education is in knowing how to use the content and the relationship among the facts (Sener, 2012). Furthermore, the mastery of core concepts and memorization of facts is not enough to succeed in the workforce (Andrews and Higson, 2008; Robles, 2012). Several sources define technical skills and knowledge as hard skills, whereas interpersonal skills, character traits, attitudes, behaviors, and people skills are soft skills. The list of some soft skills that employers are looking for include communication (writing and public speaking), listening, time management, collaboration and team work, leadership, etiquette, and problem solving (Andrews and Higson, 2008; Crosbie, 2005; Heckman and Kautz, 2012; Robles, 2012). Industry employment need surveys have identified a demand and preference for graduates possessing well-developed soft skills (Crawford et al., 2011; Hart Research Associates, 2015; Ricker, 2014). The challenge is to add exercises and activities to current classes that develop both hard and soft skills. Teaching methods focusing on the development of soft skills should be inclusive of technical knowledge and skills to maximize instructional effectiveness and perceived value of learning objectives (Hattie et al., 1996).

\section{Soft skill exercises}

All higher education courses from online to face-to-face should work to develop soft skills like listening, writing, time management, and etiquette. In all classes, students use their listening skills to learn core content and skills by listening to instructor lectures, instructions, or when watching recorded lectures or videos. Furthermore, several courses incorporate writing exercises, such as laboratory reports, summaries, essay questions, and/or discussion posts. In addition, weekly tasks and assignments contribute to improving student time management. Finally, some instructors have a set of ground rules for acceptable course participation and courtesy and respect of other students in their course syllabus leading to improved professionalism. For example, in the University of Florida, Nutritional Management of Nursery Crops course, there are two professionalism statements. The first is a statement about being a productive member of a learning community (Bali, 2016), and the second is a definition of netiquette (network or internet etiquette) along with rules adapted from the Rules of Netiquette (Ross, 1990).

In all classes, content delivered in the classroom (live or online) helps students to learn the theory and skills needed for the hands-on application of these skills (Sener, 2012). According to Crosbie (2005), the best learning is first person and is experiential with a mechanism for real-life application of skills. In face-to-face and blended classrooms, we can accomplish this without too much difficulty, but it becomes slightly more challenging in an online course and requires careful selection of different types of assignments.

\section{Examples of activities for online courses}

Ko and Rossen (2004) outline and describe several activities for improving student engagement as well as improving student soft skills in their book "Teaching Online: A Practical Guide." They suggested the use 
of scenarios and case studies to stimulate analysis and problem-based learning with a specific challenge (Ko and Rossen, 2004). In the University of Florida course Nutritional Management of Nursery Crops, we use challenge questions such as "what is wrong with my plant?" We provide students with a description of the situation and symptoms as well as any data they need to help solve the problem such as soil and/or water analysis. These are real problems observed in different situations. Their challenge is to figure out what is wrong with the plant and recommend solutions to the problem. We ask them to search the literature and then clearly state and support the problem and their solution. When using the challenge question, several soft skills are addressed such as the comprehension of a problem, application of knowledge, analysis of data, synthesis of information, and evaluation and dissemination of results as seen in the grading rubric (Table 1).

Problem-based learning and experience-based practicums help students develop problem solving skills and application of course content to different situations (Ko and Rossen, 2004). Ko and Rossen (2004) describe developing laboratory kits to send to students to complete simple experiments or to video conference class demonstrations for students to observe experiments. However, Ko and Rossen (2004) stress that before class starts, instructors need to plan and arrange these activities. For example, in the Introductory Nursery Management course at the University of Florida, we decided to conduct a series of experiments before offering the course. In one experiment, we grew impatiens (Impatiens $\times$ wallerana) in containers fertilized with five rates $[0,1 / 2,1,2$, or 3 teaspoons $($ one teaspoon $=4.9289 \mathrm{~mL})$ ] of $18 \mathrm{~N}-3.9 \mathrm{P}-10 \mathrm{~K}$ controlled-released fertilizer (Osmocote 18-9-12; Scotts, Marysville, $\mathrm{OH}$ ) applied as a top-dress and took photos and videos of the experiment in addition to collecting growth data. Students were presented the experimental objective, data, photos, and videos. They used this information to write up the results and make conclusions and decisions based on the data presented. Depending on the semester and course, the challenge question and recorded laboratory activities could be offered as a group project to encourage teamwork and collaboration.

Garrison and Cleveland-Innes (2005) state that interaction is central to the education experience and meeting the learning outcomes. They report that interaction with the instructor and other students improves student satisfaction. Moreover, peer-to-peer learning activities tend to contribute to a feeling of community and connectedness (Ouzts, 2006; Rovai, 2001). To increase student engagement and collaboration, we developed a scholars ignite assignment in our online classes. We borrowed this idea from the

Table 1. Sample challenge question grading rubric used in online environmental horticulture courses taught at the University of Florida. Next to each criterion is a list of grading criteria for maximum points on the assignment followed by a list of some soft skills assessed.

\begin{tabular}{|c|c|c|}
\hline Criterion & Grading criterion & Soft skills assessed \\
\hline $\begin{array}{l}\text { Introduction and } \\
\text { purpose }\end{array}$ & $\begin{array}{l}\text { Student clearly demonstrates an } \\
\text { understanding of the } \\
\text { problem }\end{array}$ & Writing with clarity \\
\hline Data and symptoms & $\begin{array}{l}\text { Data are complete and } \\
\text { presented in logical order }\end{array}$ & Critical observation \\
\hline Solution & $\begin{array}{l}\text { Solutions are plausible and } \\
\text { complete }\end{array}$ & $\begin{array}{l}\text { Analyzing and } \\
\text { summarizing }\end{array}$ \\
\hline $\begin{array}{l}\text { Recommendation, } \\
\text { next steps, } \\
\text { questions, and } \\
\text { conclusions }\end{array}$ & $\begin{array}{l}\text { The student has new questions } \\
\text { and ideas generated from the } \\
\text { major findings }\end{array}$ & $\begin{array}{l}\text { Explanation and } \\
\text { support of } \\
\text { conclusions; } \\
\text { making decisions }\end{array}$ \\
\hline $\begin{array}{l}\text { Quality of the } \\
\text { presentation }\end{array}$ & $\begin{array}{l}\text { Strong evidence of preparation } \\
\text { and organization. Journal } \\
\text { names, article titles, and } \\
\text { authors are sited correctly. }\end{array}$ & $\begin{array}{l}\text { Valid sources; follow } \\
\text { instructions }\end{array}$ \\
\hline
\end{tabular}

Table 2. Sample scholar ignite grading rubric used in online environmental horticulture courses taught at the University of Florida. Next to each criterion is a list of grading criteria for maximum points on the assignment followed by a list of some soft skills assessed.

\begin{tabular}{lcc}
\hline Criterion & \multicolumn{1}{c}{ Grading } & Soft skills assessed \\
\hline $\begin{array}{l}\text { Communication } \\
\text { style }\end{array}$ & $\begin{array}{c}\text { Presenter communicated the topic } \\
\text { or information clearly and } \\
\text { precisely; presentation was easy } \\
\text { to follow }\end{array}$ & $\begin{array}{c}\text { Communication; } \\
\text { listening }\end{array}$ \\
Comprehension & $\begin{array}{c}\text { Presentation was clear and } \\
\text { organized; flow of ideas was clear }\end{array}$ & $\begin{array}{c}\text { Planning and thinking } \\
\text { strategically }\end{array}$ \\
Inspiration & $\begin{array}{c}\text { Presentation was inspiring and } \\
\text { creative }\end{array}$ & $\begin{array}{c}\text { Creativity; presentation } \\
\text { skills }\end{array}$ \\
Impact & $\begin{array}{c}\text { Presentation improved (increased) } \\
\text { knowledge and/or perception }\end{array}$ & $\begin{array}{c}\text { Self-confidence; } \\
\text { professionalism }\end{array}$ \\
& on the topic & Planning and organizing \\
Content & Information presented was & \\
\hline
\end{tabular}


The use of group activities where the roles within the group rotate is one effective way to improve cooperation (Ko and Rossen, 2004). More knowledge is created when students are able to ask each other questions (Ko and Rossen, 2004). Furthermore, the use of peer editing strengthens critical review skills. When we surveyed our students about their perceptions of the scholars ignite assignment, $93 \%$ of students felt that the assignment improved their interaction with their classmates. They also liked the ability to choose their topic $(93 \%)$ and the how-to videos on making recordings, posting recordings, and general information about the assignment $(80 \%)$. Only $21 \%$ of the students liked the peer grading. Over $95 \%$ of the students surveyed about the scholars ignite assignment liked the grading rubric. We were able to objectively assess student comprehension of course topics in addition to some soft skills such as writing, listening, presentation, problem solving, and critical observation (Table 2).

\section{Conclusion}

The purpose of any educational experience is to structure the experience to achieve the defined learning outcome including the improvement of hard and soft skills (Garrison and Cleveland-Innes, 2005). Whether online or face-to-face, by choosing a variety of assignments, instructors can assess both hard and soft skills in horticulture classes. The key to success is to have planned activities that answer specific learning outcomes and clearly defined student expectations and grading criteria.

\section{Literature cited}

Allen, E., J. Seaman, R. Poulin, and T.T. Straut. 2016. Online report card tracking online education in the United States. Babson Survey Res. Group/Quahog Res. Group, Oakland, CA.

Andrews, J. and H. Higson. 2008. Graduate employability, 'soft skills' versus 'hard' business knowledge: A European study. High. Educ. Eur. 33:411-422.

Bali, M. 2016. Tips for effective online learning - Community edition. 13 May 2017. <http://www.chronicle.com/ blogs/profhacker/tips-for-effectiveonline-learning-community-edition/ 63019>.

Crawford, P., S. Lang, W. Fink, R. Dalton, and L. Fielitz. 2011. Comparitive analysis of soft skills: What is important for new graduates? Assn. Public Land-grant Univ., Washington, DC.

Crosbie, R. 2005. Learning the soft skills of leadership. Ind. Commer. Train. $37: 45-51$

Garrison, D.R. and M. Cleveland-Innes. 2005. Facilitating cognitive presence in online learning: Interaction is not enough. Amer. J. Distance Educ. 19:133148.

Hart Research Associates. 2015. Falling short? College learning and career success. Hart Res. Assoc., Washington, DC.
Hattie, J., J. Biggs, and N. Purdie. 1996. Effects of learning skills interventions on student learning: A meta-analysis. Rev. Educ. Res. 66:99-136.

Heckman, J. and T. Kautz. 2012. Hard evidence on soft skills. Labour Econ. 19:451-464.

Ko, S. and S. Rossen. 2004. Teaching online: A practical guide. 3rd ed. Routledge, New York, NY.

Mahdavian, N. 2017. American Society for Horticulture Science Scholar's Ignite competition. 13 May 2017. <http:// www.ashs.org $/$ ?page $=$ Competitions $>$.

Ouzts, K. 2006. Sense of community in online courses. Qrtly. Rev. Distance Educ. 7:285-296.

Ricker, S. 2014. The skill set more than $3 / 4$ of employers want. 23 Jan. 2017. <http://advice.careerbuilder.com/posts/ the-skill-set-more-than-of-employerswant>.

Robles, M. 2012. Executive perceptions of the top 10 soft skills needed in today's workplace. Bus. Commun. Q. 75:453465 .

Ross, S.T. 1990. The core rules of netiquette. 14 May 2017. <http://www. albion.com/netiquette/corerules.html>.

Rovai, A.P. 2001. Building classroom community at a distance: A case study. Educ. Technol. Res. Dev. 49:33-48.

Sener, J. 2012. The seven futures of American education improving learning and teaching in a screen-captured world. CreateSpace, North Charleston, SC. 